\title{
PENGEMBANGAN MODUL BERBASIS ALAM PADA POKOK BAHASAN KALOR
}

\author{
Galuh Wijayanti ${ }^{1}$, Jeffry Handhika ${ }^{2}$, Farida Huriawati ${ }^{3}$, \\ 1,2,3 IKIP PGRI MADIUN \\ Jl. Setiabudi No. 85 Madiun \\ E-mail : Galuhwijayanti333@gmail.com, jeffry.handhika@yahoo.com
}

\begin{abstract}
Abstrak
Tujuan penelitian ini adalah mengembangkan modul fisika berbasis alam untuk materi kalor. Penelitian ini merupakan penelitian pengembangan dengan adaptasi dari model pengembangan menurut Sugiyono dan model pengembangan 4-D (Four D). Sasaran dalam penelitian ini adalah modul berbasis alam pada pokok bahasan kalor untuk siswa SMP/MTs kelas VII yang diuji cobakan pada siswa SMPN 1 Takeran Magetan sebanyak 20 anak. Kelayakan modul ditinjau dari hasil validasi ahli, respon guru serta siswa. Berdasarkan hasil penelitian menunjukkan bahwa 1)hasil penilaian ahli terhadap produk pengembangan modul menyatakan baik, ahli materi $(83,9)$ dan ahli modul $(84,1), 2)$ hasil respon peserta didiksangat baik, uji kelas kecil $(89,7)$ dan uji kelas besar $(83,8), 3)$ guru mata pelajaran fisika memberikan respon yang sangat baik $(90,6)$.
\end{abstract}

Kata kunci : Modul, Kalor, Model Pengembangan 4D.

\section{PENDAHULUAN}

Pembelajaran fisika membutuhkan sarana yang baik dan tepat guna untuk mendukung tercapainya hasil sesuai dengan yang diharapkan. Salah satu sarana yang dapat mendukung adalah inovasi media ajar sebagai panduan yang memadai dan disesuaikan dengan kurikulum yang diterapkan di lembaga pendidikan. Penyusunan media ajar dapat disesuaikan dengan karakteristik lingkungan alam sekitar sekolah dan karakteristik siswa itu sendiri. Seperti yang diungkapkan Holley and Moore (2005) bahwa "method subjects were collapsed into an integrated study of theory, skills and practices of classroom work and connections were drawn between all subjects or knowledge".

Sebelum menentukan tindakan maka perlu disebar angket analisis kebutuhan (Haim Eshach: 2014). Berdasarkan observasi pendahuluan dengan menyebar angket analisis kebutuhan di SMP Negeri 1 Takeran, diperoleh informasi bahwa media ajar yang digunakan oleh siswa masih kurang. Siswa hanya menggunakan lembar kerja siswa dan buku paket yang jumlahnya tidak mencukupi yaitu satu buku paket digunakan untuk dua hingga empat siswa. Dalam buku paket tersebut hanya terdapat rumus-rumus, uraian materi, dan soal latihan sehingga pengetahuan siswa tentang fenomena-fenomena alam yang terkait dengan ilmu fisika masih minim. Selain itu, tampilan yang kurang menarik dan materi yang tidak familiar menyebabkan minat baca dan belajar siswa menjadi rendah. Hasil angket menunjukkan $90 \%$ siswa dari total 20 responden mengalami kesulitan belajar dalam memahami konsep dan hitungan matematis. Kenyataannya, siswa cenderung sulit memahami apa yang dimaksud dalam materi tersebut karena fisika merupakan salah satu pelajaran yang membutuhkan kemampuan berpikir abstrak. Akibat dari tidak pahamnya konsep, siswa juga kurang mampu memecahkan masalah hitungan matematis. Berdasarkan hasil analisis kebutuhan, 90\% siswa membutuhkan bahan ajar selain buku paket dan LKS, serta 90\% siswa membutuhkan kegiatan pembelajaran yang dapat mengaitkan materi dengan kehidupan sehari-hari. Menurut Supriadi, S.Pd, salah satu pengajar mata pelajaran fisika di SMP Negeri 1 Takeran, pengadaan modul yang menarik dianggap penting untuk menunjang kegiatan pembelajaran di kelas.

Materi yang dipilih yaitu Kalor. Sebagian besar siswa sulit memahami konsep kalor. Selain itu kalor memiliki banyak konsep "thermal physics possessesa rich of concepts, including many overlap to varying degrees with respect to a variety of aspects wich can further confuse students" (Risto Leinonen: 2013). 
Materi yang dipadukan dengan peristiwa alam dalam kehidupan sehari-hari di lingkungan sekitar dapat dijadikan salah satu alternatif pembuatan modul pembelajaran fisika maupun pelajaran lainnya. Guru dapat menyesuaikan materi ajar dengan corak lingkungan secara leluasa dan maksimal. Zhengzhou Chen (2014) mengungkapkan bahwa "visual perception impact the construction of abstract knowledge". Modul tersebut selain berisi uraian materi juga disajikan berbagai gambar peristiwa alam yang berkaitan dengan materi agar siswa lebih mudah memahami konsep maupun hitungan matematisnya. Selain itu siswa diajak untuk belajar langsung di lingkungan alam sekitar sekolah untuk observasi sehingga proses belajar tidak haya berlangsung di dalam kelas. Diharapkan siswa lebih tertarik dan menikmati karena dekat serta belajar langsung pada fenomena alam yang didalamnya terkandung unsur-unsur ilmu pengetahuan tentang fisika. Berdasarkan uraian di atas, maka diperlukan pengembangan modul berbasis alam yang mampu menarik minat dan mengatasi kesulitan belajar siswa dalam memahami konsep.

\section{METODE}

Metode penelitian yang digunakan dalam penelitian ini yaitu research and development (R\&D) yang dikembangkan oleh Thagarajan, Semmel, Semmel (1974). Menurut Sugiyono (2013) metode penelitian dan pengembangan adalah metode yang digunakan untuk menghasilkan produk tertentu dan menguji keefektifan produk tertentu. Penelitian ini bertujuan untuk menghasilkan sebuah produk dalam bidang pendidikan, yaitu modul pembelajaran. Modul pembelajaran yang dikembangkan berupa modul berbasis alam pada pokok bahasan kalor.

Subyek penelitian ini meliputi: siswa SMP Negeri 1 Takeran sejumlah 20 siswa. Untuk uji kelas kecil digunakan 6 siswa dan uji kelas besar 20 siswa. Dua orang dosen ahli materi serta ahli media dan seorang guru mata pelajaran fisika. Tempat penelitian di SMP Negeri 1 Takeran Magetan.

\section{PEMBAHASAN \\ Tahap Define}

Tahap pendefinisian meliputi: Analisis ujung depan, langkah ini digunakan untuk menentukan masalah dasar yang dihadapi dalam pembelajaran. Analisis ujung depan diperlukan pertimbangan berbagai alternatif pengembangan perangkat pembelajaran, teori belajar, tantangan, dan tuntuntan masa depan untuk menyelesaikan masalah yang dihadapi. Analisis Siswa, analisis siswa merupakan telaah karakteristik siswa yang meliputi kemampuan, latar belakang pengetahuan, dan tingkat perkembangan kognitif siswa. Analisis materi, analisis ini merupakan kumpulan prosedur untuk menentukan isi satuan pelajaran dengan mengacu pada standar isi. Analisis ini digunakan untuk mengidentifikasi materi apa yang akan digunakan untuk pengembangan dan tahap-tahap yang diperlukan untuk mencapai indikator. Mengidentifikasi konsep konsep utama yang akan disampaikan serta melakukan perumusan tujuan pembelajaran/indikator hasil belajar. Berdasarkan hasil analisis materi, pokok bahasan yang digunakan adalah kalor.

\section{Tahap Design}

Setelah tahap analisis adalah menentukan produk yang dikembangkan, produk yang dipilih untuk dikembangkan adalah Modul berbasis alam. Modul yang dibuat mengedepankan siswa belajar langsung dari contoh-contoh peristiwa alam dalam kehidupan sehari-hari, hal ini memungkinkan untuk membiasakan peserta didik belajar dengan lingkungan, serta membiasakan peserta didik menggunakan ilmu sains yang mereka miliki dalam kehidupan sehari-hari mereka. Pembelajaran diharapkan dapat bersifat dua arah dan tidak membosankan. Keanekaragaman lingkungan alam sekitar diharapkan dapat menunjang pengetahuan peserta didik serta memberi inovasi pembelajaran bagi guru.

Menentukan format, kegiatan pemilihan format merupakan tahap perancangan produk yang dikembangkan, yaitu modul berbasis alam pada pokok bahasan kalor. Sketsa awal produk yang dihasilkan adalah sebagai berikut: 


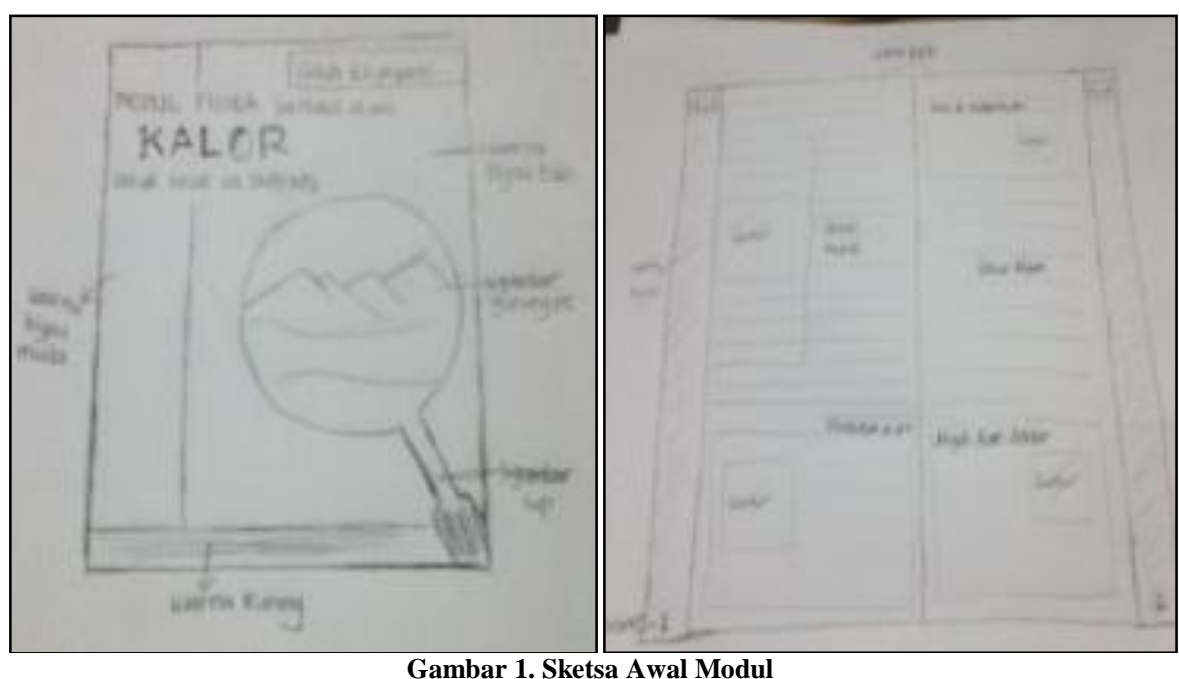

Perancangan, kegiatan selanjutnya adalah perancangan awal ini berupa draft I yang siap merancang bahan ajar berupa modul. Hasil untuk diuji oleh pakar sebagai berikut:
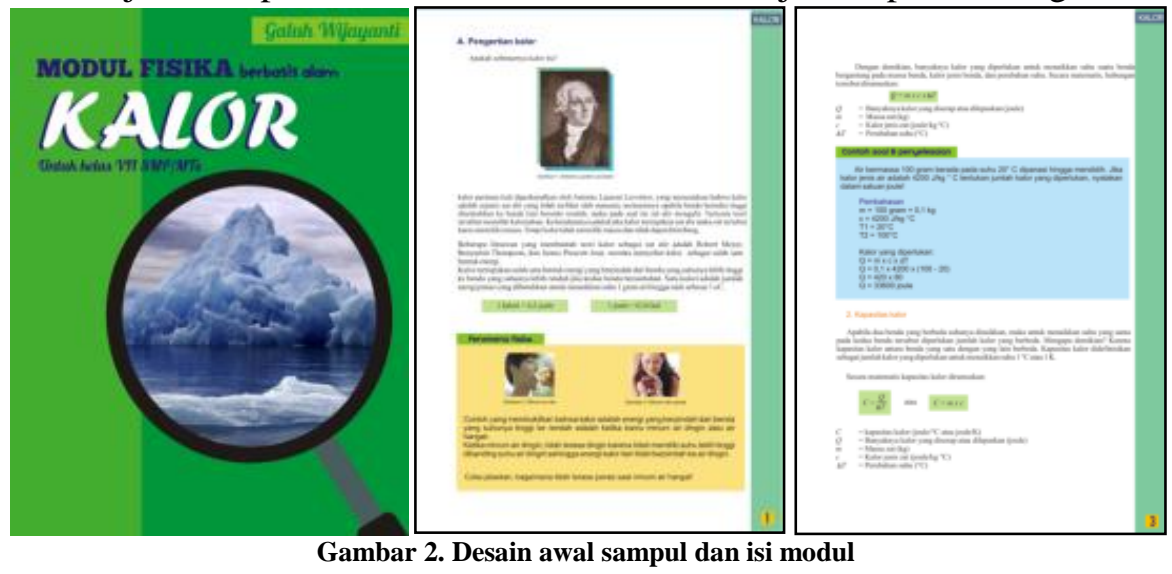

\section{Tahap Development}

Pada tahap ini dilakukan pengkajian oleh ahli modul dan ahli materi. Pengkajian ini dilakukan untuk memperoleh penilaian terhadap modul, masukan dan saran untuk perbaikan dan penyempurnaan produk. Hasil yang diberikan oleh ahli materi. Tahapan pengembangan produk disajikan pada gambar berikut:

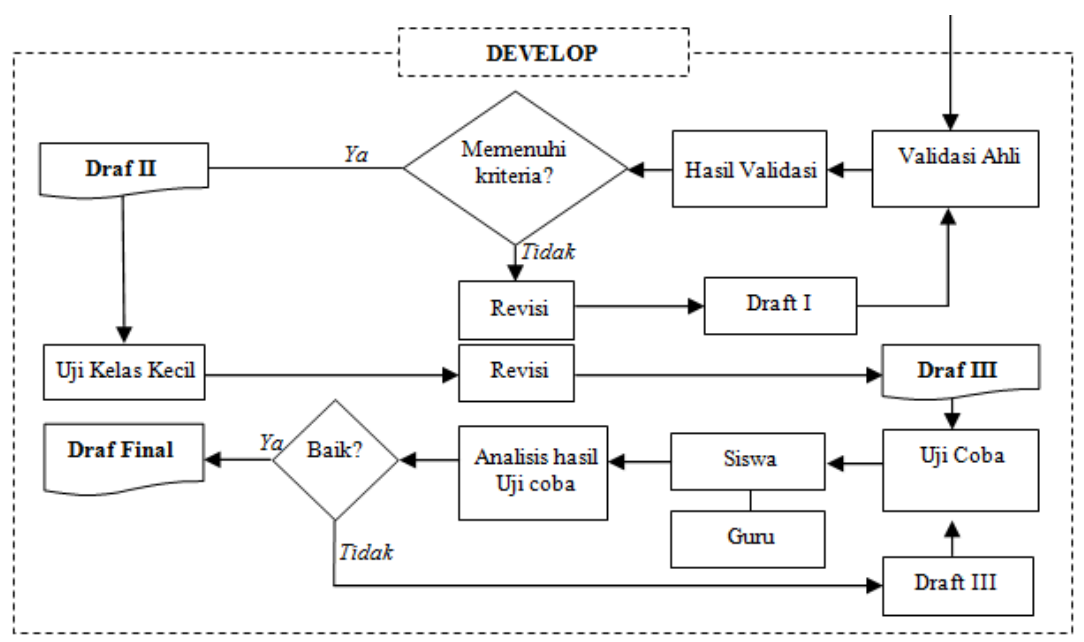

Gambar. 3 Tahapan pengembangan modul 
Hasil pengembangan produk dari kelas kecil memberikan respon dengan nilai 89,7 (kelayakan baik), respon uji kelas besar 83,8 (kelayakan baik), respon guru memberikan nilai
90,6. Adapun pakar modul dan pakar materi memberikan nilai sebagai berikut:

Tabel 1. Penilaian Ahli Modul

\begin{tabular}{c|l|c|c|c|c|c|c}
\hline \multirow{2}{*}{ No } & \multirow{2}{*}{ Aspek Penilaian } & \multicolumn{2}{|c|}{ Nilai Validator } & \multirow{2}{*}{ T } & \multirow{2}{*}{ Nilai } & \multirow{2}{*}{ Ket } \\
\cline { 3 - 7 } & & $\mathbf{1}$ & $\mathbf{2}$ & $\mathbf{3}$ & & & \\
\hline 1 & Konsistensi & 3,3 & 2,7 & 3,3 & 9,3 & 77,5 & Cukup \\
\hline 2 & Format & 3,5 & 2,5 & 4,0 & 10 & 83,3 & Baik \\
\hline 3 & Daya tarik & 3,5 & 2,8 & 4,0 & 10,3 & 85,8 & Baik \\
\hline 4 & $\begin{array}{l}\text { Bentuk dan Ukuran } \\
\text { Huruf }\end{array}$ & 3,5 & 3,0 & 3,5 & 10 & 83,3 & Baik \\
\hline \multicolumn{2}{|c|}{ Jumlah } & 13,8 & 11 & 14,8 & 39,6 & 329,9 & \\
\hline \multicolumn{2}{|c|}{ Rata-rata (M) } & $\mathbf{3 , 5}$ & $\mathbf{2 , 7}$ & $\mathbf{3 , 8}$ & $\mathbf{9 , 9}$ & $\mathbf{8 4 , 1}$ & Baik \\
\hline
\end{tabular}

Tabel 2. Penilaian Ahli Media

\begin{tabular}{|c|c|c|c|c|c|c|c|}
\hline \multirow{2}{*}{ No } & \multirow{2}{*}{ Aspek Penilaian } & \multicolumn{3}{|c|}{ Nilai Validator } & \multirow{2}{*}{$\underset{\text { Skor }}{\Sigma}$} & \multirow{2}{*}{ Nilai } & \multirow{2}{*}{ Ket } \\
\hline & & 1 & 2 & 3 & & & \\
\hline 1 & Kualitas isi & 3,5 & 2,8 & 3,7 & 10 & 83,3 & Baik \\
\hline 2 & Organisasi & 3 & 3 & 3,5 & 9,5 & 79,2 & Baik \\
\hline 3 & Kebahasaan & 3,5 & 3 & 3,5 & 10 & 83,3 & Baik \\
\hline 4 & Evaluasi & 3 & 4 & 4 & 11 & 9,2 & $\begin{array}{c}\text { Sangat } \\
\text { Baik }\end{array}$ \\
\hline \multicolumn{2}{|r|}{ 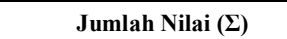 } & 13 & 12,8 & 15,7 & 40,5 & 255 & \\
\hline \multicolumn{2}{|r|}{ Rata-rata (M) } & 3,5 & 3,2 & 3,4 & & 83,9 & Baik \\
\hline
\end{tabular}

Adapun saran saran dari pakar sebagai

Setelah memperbaiki modul sesuai berikut: Pakar modul: Desain dibuat lebih menarik menarik, Pakar Materi: menambahkan kegiatan di lingkungan sekitar. saran dan masukan dari ahli materi dan ahli modul, maka diperoleh produk akhir sebagai berikut:
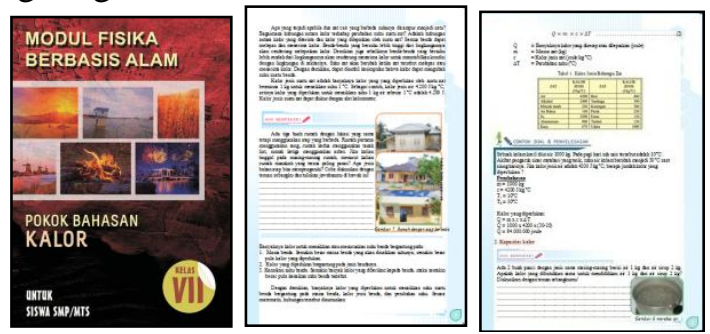

Gambar 4. Desain akhir sampul dan isi modul

\section{Tahap Desseminate}

Setelah tahap pengembangan dimana produk mendapat penlaian dan respon secara layak dari ahli, guru serta siswa maka produk siap disebarluaskan. Produk ini disebarluaskan untuk skala yang lebih besar. Pada penelitian ini kegiatan desiminasi luas belum dilakukan

\section{KESIMPULAN DAN SARAN \\ Kesimpulan}

1. Hasil penilaian yang dilakukan oleh validator terhadap produk pengembangan didapatkan hasil dengan rata-rata skor sebesar 3,35 dengan nilai sebesar 83,75. Nilai tersebut menyatakan bahwa produk pengembangan modul "baik".

2. Hasil respon peserta didik ketika dilakukan uji kelas kecil memperlihatkan respon yang baik dengan rata-rata skor sebesar 3,60 (nilai 89,70 ) dan rata-rata skor sebesar 3,34 (nilai $83,80)$ pada uji kelas terbatas. Guru mata pelajaran fisika juga memberikan respon yang sangat baik dengan rata-rata skor sebesar 3,60 (nilai 90,60). Hal ini menunjukkan bahwa produk pengembangan 
mempunyai kualitas "baik", dilihat dari respon siswa dan guru.

\section{Saran}

Dalam penelitian ini respon yang diberikan guru hanya terbatas pada satu guru saja, akan lebih baik jika dalam penelitian selanjutnya respon yang diberikan guru lebih dari satu.

\section{Ucapan Terima Kasih}

Ucapan terimakasih kami sampaikan kepada para pakar penilai, Dr. M. Nur, M.Pd., Andista Candra Yusro, S.Pd., dan Supriyadi, S.Pd.

\section{DAFTAR PUSTAKA}

Sugiyono.(2013). Metode Penelitian Pendidikan, Pendekatan kuantitatif, kualitatif dan R\&D. Alfabeta Bandung.

Thiagarajan S, Dorothy S. Semmel, Melvyn I. Semmel. (1974). Instructional Development for Training Teachers of Exceptional Children: A Sourcebook. Leadership Training Institute/Special Education, University of Minnesota

Hooley, N \& Moore, R. Changing Perceptions of Knowledge: Evaluation of an Innovative Program for Pre Service Secondary Teacher. Australian Journal of Teacher Education 30 (2). 2005.

Risto, L. Overcoming Student's Misconceptions Concering Thermal Physics with The Aid of Hints and Peer Interactions During a Lecture Course. American Physical Society. 2013.

Haim, E. Develpment of a Student-Centered Instrument to assess Middle School Students' Conceptual Understanding of Sound. American Physical Society. 2014.

Zhongzhou, C. How to Make a Good Animation: a Grounded Cognition Model of How Visual Representation Design Affects the Construction of Abstract Physics Knowledge. American Physical Society. 2014. 